\title{
HUBUNGAN KEPRIBADIAN HARDINESS DAN DUKUNGAN SOSIAL DENGAN STRATEGI COPINGPADA CAREGIVER PANTI SOSIAL DI JAKARTA
}

\author{
Yayi Ratri Kinasih \\ Rilla Sovitriana
}

Fakultas Psikologi Universitas Persada Indonesia Yayasan Administrasi Indonesia

\begin{abstract}
ABSTRAK
Penelitian ini bertujuan untuk mengetahui hubungan kepribadian hardiness dan dukungan sosial dengan strategi coping pada caregiver di Panti Sosial Bina Laras Harapan Sentosa 1. Penelitian ini menggunakan pendekatan kuantitatif dengan subjek penelitian berjumlah 38 orang yang diperoleh melalui teknik pengambilan sampel jenuh. Penelitian ini menggunakan skala strategi coping terdiri 21 item valid, skala kepribadian hardiness terdiri dari 22 item valid, dan skala dukungan sosial terdiri dari 27 item valid. Hasil penelitian menggunakan teknik Korelasi Analisis Eta dan Korelasi Multivariat Kanonik menunjukkan: 1) ada hubungan antara kepribadian hardiness dan strategi coping dengan nominal by interval Eta sebesar 0,418 >r product table 0,312. 2) ada hubungan antara dukungan sosial dan strategi coping dengan nominal by interval Eta sebesar 0,324 >r product table 0,312. 3) ada hubungan kepribadian hardiness dan dukungan sosial dengan strategi coping dimana nilai canon correlation 1 sebesar 0,477 dan nilai canon correlation 2 sebesar 0,315 yang lebih besar dari $r$ product table 0,312 .
\end{abstract}

Katakunci : Strategi Coping, Kepribadian Hardiness, Dukungan Sosial 


\section{PENDAHULUAN}

Secara umum gangguan jiwa dapat dibagi menjadi dua golongan yaitu psikosis dan non-psikosis. Salah satu penyakit yang termasuk dalam jenis psikosis adalah skizofrenia.

Menurut data dari World Health Organization pada tahun 2016 terdapat 21 juta orang menderita skizofrenia. Kemudian data Riset Kesehatan Dasar pada tahun 2013 (dalam http://www.depkes.go.id/)menunjukkan prevalensi gangguan jiwa berat seperti skizofrenia mencapai sekitar 400 ribu orang atau sebanyak 1,7 per 1.000 penduduk di Indonesia.

Penderita skizofrenia memiliki gejala positif dan negatif. Gejala positif antara lain, delusi, halusinasi, kekacauan alam pikir, gaduh gelisah, dan menyimpan rasa permusuhan. Sedangkan gejala negatif antara lain, afek yang tumpul dan datar, menarik diri atau mengasingkan diri, tidak mau bergaul dengan orang lain, kontak emosional amat miskin, pasif dan apatis, pola pikir stereotip, serta kehilangan kehendak (Hawari, 2015 : 275).

$\begin{array}{ccr}\text { Gejala } & \text { penyakit } & \text { skizofrenia } \\ \text { menyebabkan } & \text { penderitanya } & \text { memiliki }\end{array}$

perilaku yang dinilai tidak wajar dan dianggap berbahaya. Oleh karena itu, seringkali ditemukan penderita skizofrenia yang tidak dirawat oleh keluarga, diusir, dan dibiarkan menggelandang.

Oleh karena itu, Undang-Undang Republik Indonesia Nomor 8 Pasal 1 Tahun 2016 tentang Penyandang Disabilitas menyebutkan bahwa pemerintah berupaya secara sadar untuk melindungi, mengayomi, dan memperkuat hak penyandang disabilitas.

Hal tersebut dilakukan dengan menyediakan Unit Layanan Disabilitas berupa satu institusi atau lembaga yang berfungsi sebagai penyedia layanan dan fasilitas untuk Penyandang Disabilitas dengan membentuk suatu Panti Sosial.

Panti Sosial Bina Laras Harapan Sentosa 1 (PSBL Harapan Sentosa 1) ditujukan untuk penderita skizofrenia terlantar di Provinisi DKI Jakarta. Menurut data dari PSBL Harapan Sentosa 1 pada tahun 2017 jumlah penghuni di panti tersebut berjumlah 851 orang. 
Berdasarkan hasil wawancara diketahui bahwa beban kerja caregiver di PSBL Harapan Sentosa 1 tergolong tinggi. Beban yang dirasakan caregiver dapat mengancam kesehatan fisik, psikologis, dan emosional (Zarit et al., Parks \& Novielli, Etters et al., Carretero et al., dalam Kim et al., 2012). Lebih lanjut, beban kerja secara tidak langsung dapat menimbulkan stres kerja yang menghambat kinerja individu (Robbins dalam Ummu, 2011 : 65).

Untuk menghadapi suatu situasi yang menimbulkan tekanan atau stres diperlukan sebuah cara yang disebut dengan strategi coping. Coping adalah sebuah usaha, baik berupa tindakan dan intrapsikis, untuk mengatur (yaitu, menguasai, mentolerir, mengurangi, memperkecil) tuntutan lingkungan dan diri sendiri, serta konflik diantara mereka, yang membebani atau melebihi sumber daya seseorang (Cohen \& Lazarus, dalam Cohen, 1995 : 283).

Kemudian dalam penelitian yang dilakukan oleh Judkins (2002 : 81) menunjukkan bahwa perawat dengan tingkat hardiness tinggi menggunakan stategi coping berbeda dengan perawat yang tingkat hardiness-nya rendah.
Hardiness adalah sikap-sikap yang membuat orang tahan stress. (Kobasa, dalam Taylor, Peplau, \& Sears, 2009 : 554).

Kepribadian hardiness merupakan faktor internal jadi diperlukan pula faktor eksternal untuk optimalisasi peran strategi coping, yaitu dukungan sosial. Dukungan sosial ialah perasaan memiliki, adanya penerimaan, merasa dicintai atau dibutuhkan (Greenberg, 2011 : 117).

Adapun penelitian oleh Nur Saadah dan Abdullah (2015 : 177) menemukan bahwa semua subjek caregiver dalam penelitiannya membutuhkan dukungan sosial yang dapat membantu caregiver mengurangi situasi menekan dengan cara yang baik

Berdasarkan uraian tersebut, peneliti tertarik untuk membuat sebuah penelitian berjudul "Hubungan Antara Kepribadian Hardiness dan Dukungan Sosial dengan Strategi Coping pada Caregiver Panti Sosial Bina Laras Harapan Sentosa 1 di Jakarta Barat”. 


\section{TINJAUAN PUSTAKA}

\section{Strategi Coping}

Menurut Sarafino dan Smith (2011 : 111) coping adalah proses yang dilakukan seseorang untuk mengatur perbedaan antara tuntutan dan sumber daya yang mereka nilai dalam sebuah situasi stres.

Menurut Lazarus (1993 : 238) coping terdiri dari dua fungsi utama, yaitu problem-focused coping dan emotionfocused coping. Problem focused coping berfungsi untuk merubah masalah dalam hubungan individu dan lingkungan. emotion focused coping berfungsi untuk merubah cara individu menghadapi kondisi penuh stres.

Lebih lanjut, aspek-aspek problem focused coping oleh Aldwin \& Revenson (dalam Emma, 2006 : 72) antara lain:

\section{Cautiousness}

Sikap dimana individu berpikir dan mempertimbangkan beberapa alternatif pemecahan masalah yang tersedia

\section{Instrumental Action}

Tindakan individu yang diarahkan pada penyelesaian masalah secara langsung, serta menyusun langkah yang akan dilakukannya.

\section{Negotiation}

Negosiasi merupakan beberapa usaha yang ditujukan kepada orang untuk ikut menyelesaikan masalah.

Sementara itu, aspek-aspek emotional focused coping menurut Aldwin dan Revenson (dalam Indirawati, $2006: 73$ ) terbagi menjadi:

1. Escapism

Perilaku menghindari masalah dengan membayangkan seandainya berada dalam situasi lain yang lebih menyenangkan.

\section{Minimization}

Tindakan menganggap masalah yang dihadapi jauh lebih ringan daripada yang sebenarnya.

3. Self Blame

Cara menghadapi masalah dengan menghukum diri secara berlebihan dan menyesali tentang apa yang telah terjadi.

\section{Seeking Meaning}

Individu mencari hikmah atau pelajaran yang dapat dipetik dari masalah yang telah atau sedang dihadapi.

Beberapa faktor yang memengaruhi strategi coping menurut Smet (1994 : 130) yaitu sebagai berikut: 
1. Variabel kondisi individu: umur, tahap kehidupan, jenis kelamin, temperamen, faktor genetik, inteligensi, pendidikan, suku, kebudayaan, status ekonomi, dan kondisi fisik.

2. Karakteristik kepribadian: introvert ekstrovert, stabilitas emosi, kepribadian tipe A, kepribadian hardiness, locus of control.

3. Variabel sosial-kognitif: dukungan sosial yang dirasakan, jaringan sosial, dan kontrol pribadi yang dirasakan.

4. Hubungan dengan lingkungan sosial, dukungan sosial yang diterima, dan integrasi dalam jaringan sosial.

\section{Kepribadian Hardiness}

Kobasa, Maddi, dan Kahn (1982 : 169) mengemukakan hardiness sebagai sebuah kumpulan dari karakteristik kepribadian yang berfungsi sebagai sumber perlawanan dalam menghadapi peristiwa hidup yang penuh stres.

Menurut Kobasa, Maddi, dan Kahn (1982 : 169) kepribadidan hardiness dibagi menjadi tiga, yaitu :

\section{a. Commitment (Komitmen)}

Individu mampu mengenali dan mencari makna dari peristiwa, masalah, dan orang lain dalam lingkungannya.

b. Control (Kontrol)

Meningkatkan kemungkinan bahwa perisitwa akan dialami sebagai hasil alami dari tindakan seseorang dan bukan sebagai pengalaman yang asing, tidak terduga, dan luar biasa.

c. Challenge (Tantangan)

Tantangan meringankan persepsi akan peristiwa stres dengan menganggap peristiwa stres membangkitkan semangat dengan menyesuaikan diri sesuai perubahan.

\section{Dukungan Sosial}

Taylor (2015: 148) mendefinisikan dukungan sosial sebagai informasi dari orang lain bahwa mereka dicintai dan dipedulikan, dihormati dan dihargai, serta menjadi bagian dari jaringan komunikasi dan kewajiban bersama.

Menurut Sarafino dan Smith (2011 : 81) dukungan sosial terdiri dari empat jenis, yaitu:

a. Dukungan emosional atau penghargaan

Dukungan ini mencakup ungkapan rasa empati, kepedulian, perhatian, rasa hormat, dan semangat terhadap individu yang bersangkutan. 
b. Dukungan instrumental

Bentuk dukungan ini mencakup bantuan langsung misalnya yang berupa bantuan keuangan atau bantuan dalam mengerjakan tugastugas tertentu.

c. Dukungan informasi

Dukungan yang bersifat informasi ini dapat berupa nasehat, pengarahan, saran-saran, atau umpan balik tentang apa yang harus dilakukan.

d. Dukungan pertemanan

Dukungan ini berkenaan dengan memberikan perasaan keanggotaan dalam kelompok

\section{HIPOTESIS}

Dalam penelitian ini, terdapat tiga hipotesis yang akan diuji.Hipotesis pertama $\left(\mathrm{Ha}_{1}\right)$ ialah"ada hubungan antara strategi coping dengan kepribadian hardiness pada caregiver di PSBL Harapan Sentosa 1"

Hipotesis kedua $\left(\mathrm{Ha}_{2}\right)$ adalah "ada hubungan antara strategi coping dengan dukungan sosial pada caregiver di PSBL Harapan Sentosa 1"

Hipotesis ketiga $\left(\mathrm{Ha}_{3}\right)$ yaitu "ada hubungan antara strategi coping dengan kepribadian hardiness dan dukungan sosial pada caregiver di PSBL Harapan Sentosa 1"

\section{METODOLOGI}

Populasi yang akan digunakan dalam penelitian ini adalahcaregiver PSBL Harapan Sentosa 1 dengan menggunakan teknik pengambilan sampel jenuh.Total sampel merupakanjumlah seluruh populasi, yakni 38 caregiverPSBL Harapan Sentosa 1.

Dalam penelitian ini metode pengumpulan data yang digunakan adalah skala psikologi yang disusun berdasarkan model skala Likert. Pernyataan-pernyataan dalam skala ini terdiri dari pernyataan favourable dan unfavourable dengan menggunakan lima alternatif jawaban.

Dalam penelitian ini metode yang digunakan dalam menguji hipotesis dan menganalisa data menggunakan metodeKorelasi Analisis Eta dan Multivariate Corellations dengan Korelasi Kanonik.

\section{ANALISIS DATA \\ DAN PEMBAHASAN}

Hasil analisis data penelitian pada hipotesis pertama dengan menggunakan Korelasi Analisis Eta antara variabel 
kepribadian hardiness dengan strategi coping didapatkan nominal by interval Eta $=0,418>\mathrm{r}$ product table 0,312 . Hal ini berarti $\mathrm{Ho}_{1}$ di tolak dan $\mathrm{Ha}_{1}$ yang berbunyi "ada hubungan kepribadian hardiness dengan strategi coping pada caregiver PSBL Harapan Sentosa 1" diterima.

Hal ini sejalan dengan pendapat Kobasa (1979) yang mengatakan bahwa kepribadian hardiness memengaruhi kemampuan penilaian individu terhadap situasi stres dan kemampuan strategi coping yang dimiliki. Adapun hasil penelitian oleh Judkins (2002 : 52) menyebutkan bahwa terdapat hubungan yang signifikan antara kepribadian hardiness dan strategi coping.

Pada hipotesis kedua dengan menggunakan Korelasi Analisis Eta didapatkan hasil analisis data antara dukungan sosial dengan strategi coping darinominal by interval Eta $=0,324>\mathrm{r}$ product table 0,312 . Hal ini berarti bahwa $\mathrm{Ho}_{2}$ di tolak dan $\mathrm{Ha}_{2}$ yang berbunyi "ada hubungan dukungan sosial dengan strategi coping pada caregiver PSBL Harapan Sentosa 1" diterima.

Hal ini sejalan dengan pendapat Wortman dan Dunkel-Schetter (dalam Sarafino \& Smith, 2011 : 118) bahwa individu dengan kemampuan coping yang baik dalam menghadapi situasi stres ialah individu yang mendapat dukungan dari orang lain dibandingkan dengan individu yang memiliki strategi coping kurang baik.Kemudian hasil penelitian Nur Hasan \& Elina (2013 : 54) menunjukkan ada hubungan signifikan antara dukungan sosial dengan strategi coping.

Pada hipotesis ketiga diperoleh nilai canon correlation pertama $=0,477$ dan nilai canon correlation kedua $=0,315$ yang lebih besar dari $\mathrm{r}$ product table 0,312. Hal ini berarti bahwa $\mathrm{Ho}_{3}$ di tolak dan $\mathrm{Ha}_{3}$ yang berbunyi "ada hubungan antara kepribadian hardiness dan dukungan sosial dengan strategi coping pada caregiver PSBL Harapan Sentosa 1" diterima.

\section{KESIMPULAN}

Dari hasil analisis data pada penelitian ini dapat diambil kesimpulan bahwa ada hubungan yang signifikan antara kepribadian hardiness dengan strategi coping pada caregiver PSBL Harapan Sentosa 1. Hal ini berarti karakteristik kepribadian hardiness pada caregiver dapat memengaruhi pemilihan strategi coping individu tersebut. 
Kemudian dapat diketahui bahwa ada hubungan antara dukungan sosial dengan strategi coping pada caregiver PSBL Harapan Sentosa 1. Hal ini berarti dukungan sosial yang diterima atau dirasakan caregiver dapat memengaruhi pemilihan strategi coping individu tersebut.

Kemudian hasil penelitian juga mengemukakan bahwa terdapat hubungan yang signifikan antara kepribadian hardiness dan dukungan sosial dengan strategi coping pada caregiver PSBL Harapan Sentosa 1. Hal ini berarti karakteristik kepribadian hardiness dan dukungan sosial yang dirasakan caregiver dapat memengaruhi pemilihan strategi coping individu tersebut.

\section{DAFTAR PUSTAKA}

Cohen, Frances. (1995). Measurement of Coping. Dalam Kasl, S.V., \& Cooper, C.L (Eds.), Research Methods in Stress and Health Psychology (Pp. 283 - 301). England : John Wiley \& Sons Ltd.

Dadang Hawari. (2015). Ilmu Kedokteran Jiwa dan Kesehatan Jiwa dalam Perspektif Al-Qur'an dan As-Sunnah (Edisi 2). Jakarta : Badan Penerbit FKUI.
Dimatteo, Robin. M. (1991). The Psychology of Health, Illness, and Medical Care: An Individual Perspective. California : Brooks/Cole Publishing Company.

Emma Indirawati. (2006). Hubungan Antara Kematangan Beragama dengan Kecenderungan Strategi Coping. Jurnal Psikologi Universitas Diponegoro, Vol. 3, No. 2

Fitri Fausiah. (2007). Psikologi Abnormal Klinis Dewasa. Jakarta : UI-Press.

Greenberg, Jerrold S. (2011). Comprhensive Stress Management $12^{\text {th }}$ Edition. New York : Mc-Graw Hill.

Judkins, Sharon, K. (2002). Hardiness, Stress, and Coping Strategies Among Mid-Level Nurse Managers. USA : ProQuest, UMI Number: 3056800.

Kim, H., Chang, M., Rose, K., \& Kim, S. (2012). Predictors of Caregiver Burden in Caregivers of Individuals With Dementia. Journal of Advanced Nursing. USA : Blackwell Publishing Ltd ( 68(4), 846-855).

Kobasa, S.C. (1979). Stressful Life Events, Personality, and Health: An Inquiry Into Hardiness. Journal of Personality and Social Psychology, Vol. 37, No. 1.

Kobasa, S.C., Maddi, S.R., Kahn, S. (1982). Hardiness and Health: A Pospective Study. Journal of 
Personality and Social Psychology, Vol. 42, No. 1, 168 - 177.

Lazarus, Richard. S. (1993). Coping Theory and Research: Past, Present, and Future. Psychosomatic Medicine, $55: 234-247$.

Nur Hasan \& Elina Raharisti Rufaidah. (2013). Hubungan Antara Dukungan Sosial dengan Strategi Coping pada Penderita Stroke RSUD Dr. Moewardi Surakarta. Talenta Psikologi, Vol. II, No. 1.

Nur Saadah, M.A., Abdullah, H. (2015). Strategi Daya Tindak dan Program Sokongan Sosial Untuk Penjaga Tidak Formal. Journal of Social Sciences and Humanities, Vol. 10, No. 1, 170 183.

Sarafino, E.P., Smith, T.W (2011). Health Psychology: Biopsychosocial Interactions $7^{\text {th }}$ Edition. Canada: John Wiley \& Sons, Inc.

Smet, Bart. (1994). Psikologi Kesehatan. Jakarta : PT Grasindo.

Taylor, S. E. (2015). Health Psychology Ninth Edition. New York : McGrawHill.

Taylor, Shelley E., Peplau, Letitia A., \& Sears, David O. (1997). Social Psychology (Ninth Edition). New Jersey : Prentice-Hall. Inc.

Ummu Hany Almasitoh. (2011). Stres Kerja Ditinjau dari Konflik Peran Ganda dan Dukungan Sosial pada
Perawat. Jurnal Psikologi Islam, Vol. 8 No. $1,63-82$. 